\title{
Detection and characterization of volcanic ash plumes over Lille during the Eyjafjallajökull eruption
}

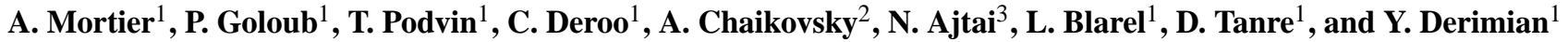 \\ ${ }^{1}$ Laboratoire d'Optique Atmosphérique, CNRS, UMR8518, Université Lille 1, Villeneuve d'Ascq, France \\ ${ }^{2}$ Laboratory of Optics of Scattering Media, Stepanov Institute, Academy of Science of Belarus, Minsk, Belarus \\ ${ }^{3}$ Research Center for Disaster Management, Faculty of Environmental Science and Engineering, Babeş-Bolyaï University, \\ Cluj-Napoca, Romania
}

Correspondence to: A. Mortier (augustin.mortier@ed.univ-lille1.fr)

Received: 29 October 2012 - Published in Atmos. Chem. Phys. Discuss.: 4 December 2012

Revised: 4 March 2013 - Accepted: 13 March 2013 - Published: 4 April 2013

\begin{abstract}
Routine sun-photometer and micro-lidar measurements were performed in Lille, northern France, in April and May 2010 during the Eyjafjallajökull volcanic eruption. The impact of such an eruption emphasized significance of hazards for human activities and importance of observations of the volcanic aerosol particles. This paper presents the main results of a joint micro-lidar/sun-photometer analysis performed in Lille, where volcanic ash plumes were observed during at least 22 days, whenever weather conditions permitted. Aerosol properties retrieved from automatic sun-photometer measurements (AERONET) were strongly changed during the volcanic aerosol plumes transport over Lille. In most cases, the aerosol optical depth (AOD) increased, whereas Ångström exponent decreased, thus indicating coarse-mode dominance in the volume size distribution. Moreover, the non-spherical fraction retrieved by AERONET significantly increased. The real part of the complex refractive index was up to 1.55 at $440 \mathrm{~nm}$ during the eruption, compared to background data of about 1.46 before the eruption. Collocated lidar data revealed that several aerosol layers were present between 2 and $5 \mathrm{~km}$, all originating from the Iceland region as confirmed by backward trajectories. The volcanic ash AOD was derived from lidar extinction profiles and sun-photometer AOD, and its maximum was estimated around 0.37 at $532 \mathrm{~nm}$ on 18 April 2010. This value was observed at an altitude of $1700 \mathrm{~m}$ and corresponds to an ash mass concentration (AMC) slightly higher than $1000 \mu \mathrm{g} \mathrm{m}^{-3}( \pm 50 \%)$. An effective lidar ratio of ash particles of $48 \mathrm{sr}$ was retrieved at $532 \mathrm{~nm}$ for 17 April during the early stages of the eruption, a value which agrees
\end{abstract}

with several other studies carried out on this topic. Even though the accuracy of the retrievals is not as high as that obtained from reference multiwavelength lidar systems, this study demonstrates the opportunity of micro-lidar and sunphotometer joint data processing for deriving volcanic AMC. It also outlines the fact that a network of combined microlidars and sun photometers can be a powerful tool for routine monitoring of aerosols, especially in the case of such hazardous volcanic events.

\section{Introduction}

The Eyjafjallajökull eruption started on 20 March 2010, but the eruptive intensity significantly increased on 14 April, resulting in large amounts of ash being injected into the atmosphere (Sigmundsson et al., 2010). This event strongly affected the European and global air transport industry since volcanic ash (VA) plumes were subjected to long-range transport and carried over large areas in Central Europe due to strong westerly winds.

Volcanism in general is a very dynamic geological process that has spectacular manifestations, but at the same time is associated with several risk factors that often severely affect human life and the environment. The most important hazards associated with volcanic eruptions are represented by lava flows, mud flows, gas emissions, and solid fragments originating from deep within Earth that are expelled to the surface in an explosive volcanic eruption (pyroclastics) (Guffanti et al., 2009). The materials generated by such an event 
are spread much faster and on a much larger surface than the lava. Pyroclastics can be represented by volcanic bombs, lapilli (rocks with diameters varying from a few $\mathrm{mm}$ to several $\mathrm{cm})$, VA with very small particle sizes $(1 / 16-2 \mathrm{~mm})$ and very fine dust particles $(<1 / 16 \mathrm{~mm})$ consisting of fragments of glassy lava and volcanic rock particles in an amorphous or crystalline structure. VA may cause significant damage due to the fact that after being expelled into the atmosphere to a very high altitude, it is subjected to long-range particle transport phenomena, and usually falls down on large surfaces. Ash deposits are also a serious hazard to crops, and can also lead to clogging of water surfaces and collapse of poorly constructed buildings. In all cases, volcanic ash expelled to high altitudes in the atmosphere can pose a serious hazard to aircraft engines. VA has a highly corrosive effect, primarily on turbines as they get temporarily or definitively blocked after aspirating the dust, which melts at high temperatures inside the combustion chamber, and then cools down and solidifies on the cooler parts of the engine, causing sudden engine failure. VA poses a hazard also to turbine blades and causes friction scratches on the windshield, resulting in poor visibility (Ajtai et al., 2010). The International Air Transport Association (IATA, http://www.iata.org/) estimated that airline companies worldwide lost about 150 million $€$ each day during the April-May 2010 event, with total losses exceeding 2.5 billion $€$.

Monitoring of such hazardous atmospheric particles remains a difficult task since aerosol particles are highly inhomogeneous and variable in time and space. Consequently, aerosol observations have to be global and continuous. Although ground-based aerosol remote sensing does not provide global coverage, it contributes significantly to the understanding of aerosols properties and potential impacts associated, thanks to their distribution and organization within regional or global networks such as the AERONET federation. AERONET manages automatic sun photometers providing wide angular and spectral measurements of solarand sky radiation best suited to reliably and continuously derive the detailed aerosols optical properties in key locations worldwide. Moreover many atmospheric stations have vertical sounding capabilities thanks to lidar systems. Several networks dedicated to atmospheric monitoring with sun/sky photometers, lidar and in situ monitoring systems were developed in the recent past (EARLINET, MPLET, CIS-LINET, SPALINET, ROLINET, RADO, etc.). Several studies and projects demonstrated the relevance of sunphotometer and lidar systems combination in order to improve aerosol characterization and monitoring (Welton et al., 2000; Campbell et al, 2002; Pelon et al., 2008; Ansmann et al., 2010, 2011; Leon et al., 2009; Schuman et al., 2011; Mattis et al., 2010; Mona et al., 2012). In situ measurements performed by Schumann et al. (2011) revealed that the VA plumes observed over Europe consisted mainly of ash particles with radii larger than $0.5 \mu \mathrm{m}$ and sulfuric acid. The assessment of the potential associated risk therefore requires as accurate as possible determination of their location within the atmospheric column, concentration, and microphysical and chemical properties. Remote sensing measurements were performed at many atmospheric stations in Europe during this event. Among them was a sun-photometer/micro-lidar system that conducted continuous observations in Lille during that period. The micro-lidar used was the Cloud and Aerosol Micro Lidar (CAML) developed by CIMEL (Pelon et al., 2008; Leon et al., 2019). The data is archived at LOA and processed routinely to derive aerosol extinction profiles and effective lidar Ratio, thus providing a real-time overview of aerosol layers over Lille (http://www-loa.univ-lille1.fr/Instruments/LIDAR/).

The paper presents the results of monitoring and characterization of volcanic ash characteristics as observed from Lille Atmospheric Observatory during April-May 2010. Our work shows that such an important parameter as AMC can be estimated with reasonable accuracy through combination of a single-wavelength backscattering micro-lidar with AERONET. Although the results are not as accurate as those obtained from reference multiwavelength lidars (Ansmann et al., 2010), they show that the association of micro-lidars with sun photometers significantly helps in the characterization and quantification of aerosols. Such an approach is suitable for micro-lidar systems collocated with AERONET stations. In several European countries, meteorological agencies decided to either develop lidar networks (Météo France, Met Office, etc.) or update their ceilometer networks (Flentje et al., 2010) in order to support decision-making in the case of volcanic or industrial hazardous events. In our paper we aim to show that automatic, well-characterized and wellmaintained micro-lidar systems with routine operation coupled with a sun/sky photometer can be a quite relevant tool for estimating useful microphysical parameters in the case of natural or industrial hazardous events.

The paper is structured as follows: Sect. 2 is dedicated to the description and analysis of aerosol columnar properties retrieved from AERONET and of height-resolved data available from lidar, separately. In Sect. 3 the paper presents the results of joint sun-photometer/lidar inversion performed for a selection of relevant atmospheric situations between 16 April and 20 May 2010. In the last section, methodology for estimating AMC is presented, along with associated uncertainties, results and discussions.

\section{Observations and analysis}

\subsection{AERONET data from Lille during April and May 2010}

Atmospheric radiation measurements and aerosol characterization started in Lille at the LOA in 1980. However, observation on regular basis started only in 1992 within the AERONET federation (Holben et al., 1998, 2001; 


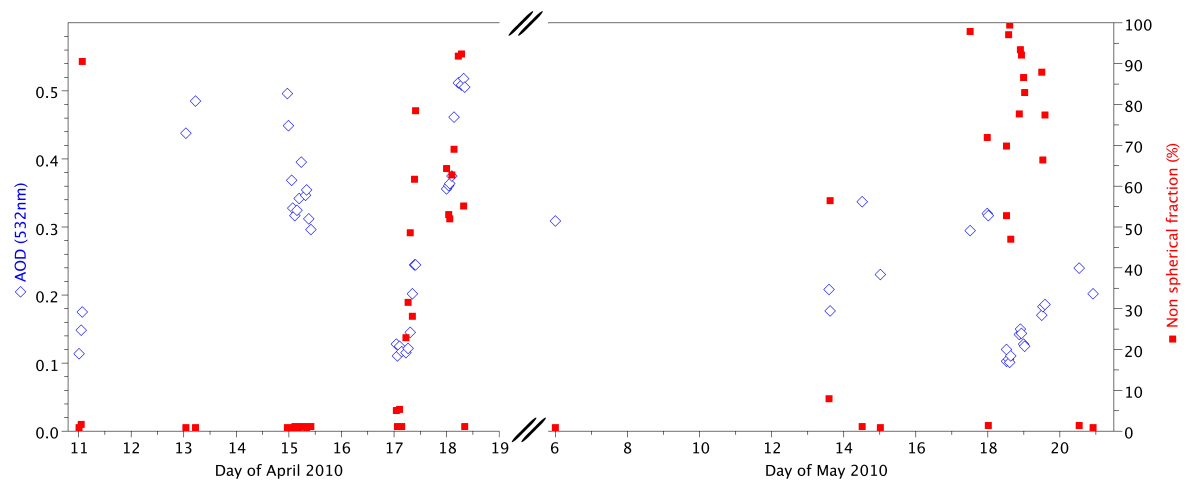

Fig. 1. Time series of AOD at $532 \mathrm{~nm}$ (blue) and fraction in \% (red squares) of non-spherical particles for April and May 2010 over Lille.

http://aeronet.gsfc.nasa.gov). Since 1992, as one of the first AERONET sites, Lille is operating one automatic CIMEL CE-318 sun photometer and performs routine observations on the roof of the physics department. AERONET is now a well-known and established network, dedicated to realtime characterization and monitoring of aerosol properties (Dubovik et al., 2000, 2002a, b, 2006) and water vapor content as well as cloud optical depth (COD) (Marshak et al., 2004). Standard measurements performed by the CIMEL CE-318 sun photometer are composed of solar spectral irradiance used to derive accurate spectral extinction AOD $( \pm 0.01)$ within the range 340 to $1640 \mathrm{~nm}$ as well as downward sky spectral radiances (440 to $1020 \mathrm{~nm}$ ) in the solar principal plane and in the almucantar geometries. Additional to spectral AOD, from which Angström exponent (AE) is computed, the main aerosol parameters retrieved that are considered in this study are the following: volume size distribution (VSD), non-spherical fraction (NSF), spectral single-scattering albedo (SSA), spectral refractive index (RI), as well as extinction-to-backscatter ratio, also called lidar ratio (LR) close to the inverse of the aerosol phase function (APF) in the backscattering direction. The AERONET retrieval scheme considers a mixture of polydisperse, randomly oriented homogeneous spheroids with a fixed distribution of aspect ratios (Mishchenko et al., 1997) and provides fraction (in percentage) of spherical particles (Dubovik et al., 2006). The AERONET retrieval products used in this study were collected in cloud-free conditions, provided by the AERONET web site as "version 2 (V2) inversion products" using the Smirnov et al. (2000) cloud-screening algorithm.

The variability of AOD, AE and NSF during April-May period is summarized in Figs. 1 and 2. Observations show that on 15 April, AOD was reaching 0.5 at $532 \mathrm{~nm}$, whereas $\mathrm{AE}$ was high and ranging between 1.5 and 1.8. The NSF was very close to zero, indicating the predominance of spherical particles. These conditions are typical for a polluted atmosphere (AOD reaching, however, almost 3 to 5 times the background level of 0.15 , as given from a multiyear analy- sis), encountered in Lille city when air masses are mainly coming from the east and northeast. On 16 April, due to clouds and rain washing out the lower troposphere, weather conditions did not permit observations. The first obvious change in aerosol properties was detected over Lille on 17 April in the morning. On this day, AOD values were not as high as on 15 April, but exhibited strong diurnal variations. The value of AOD (532 nm) reached its maximum (0.5-0.6) on 18 April. Figure 2 exhibits a sudden AE decrease, indicating an increase of the aerosol average size within the atmospheric column. At the same time, NSF sharply increased up to $50 \%$ and then to $100 \%$. The diurnal variations observed on 17 April show that AOD almost doubled between 14:00 UTC (0.13) and 17:00 UTC (0.25). On 18 April the diurnal variation exhibits a similar behavior to that of 17 April, with AOD values close to 0.35 in the morning and then strongly increasing in the afternoon, finally reaching 0.52 .

Regarding VSD retrieved from AERONET Level 2 data, important changes were observed from 15 to 18 April, as shown in Fig. 3. This figure shows that on 15 April, size distribution was mostly characterized by fine-mode domination (common for Lille), with relatively high loading (average AOD is about 0.35). In the morning on 17 April, the atmosphere was rather clean $(\mathrm{AOD} \approx 0.12)$, but became more turbid (AOD and coarse-mode concentration increased) in the afternoon, when AOD reached $\approx 0.24$. A continuous increase in AOD and coarse-mode concentration was observed until 18 April, with AOD values reaching $\approx 0.36$ in the morning and 0.51 in the afternoon. The coarse-mode concentration was mainly represented by a range of particle radii around $1.5-2 \mu \mathrm{m}$, a fact confirmed by a complementary study performed over Lille (Derimian et al., 2012) and over Paris, located around $200 \mathrm{~km}$ south of Lille (Chazette et al., 2012).

AERONET retrievals provided for 15 April an RI of $1.46 \pm 0.03$ and an SSA of $0.91 \pm 0.03$ and $0.87 \pm 0.03$ at $440 \mathrm{~nm}$ and $870 \mathrm{~nm}$, respectively. Climatologic values computed from a multiyear analysis provided for Lille an average RI of $1.42 \pm 0.03$ and an average SSA value of $0.93 \pm 0.03$ and $0.89 \pm 0.03$ at 440 and $870 \mathrm{~nm}$, respectively. On 17 


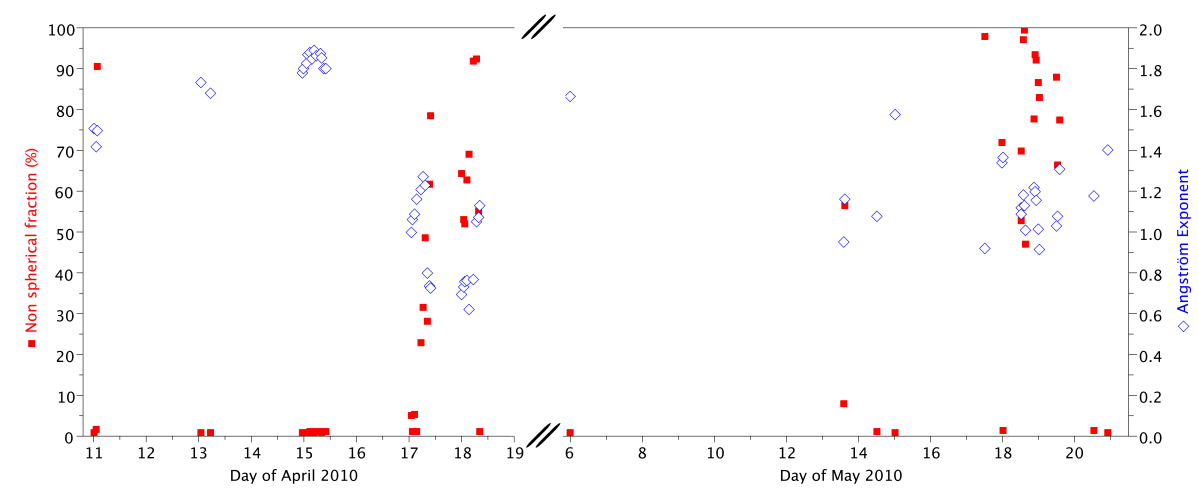

Fig. 2. Time series of Angström exponent, $\alpha=-\mathrm{d} \ell n(\mathrm{AOD}) / \mathrm{d} \ell n(\lambda)$, computed between 440 and $870 \mathrm{~nm}$ and fraction in $\%$ (red squares) of non-spherical particles for April and May 2010 over Lille.

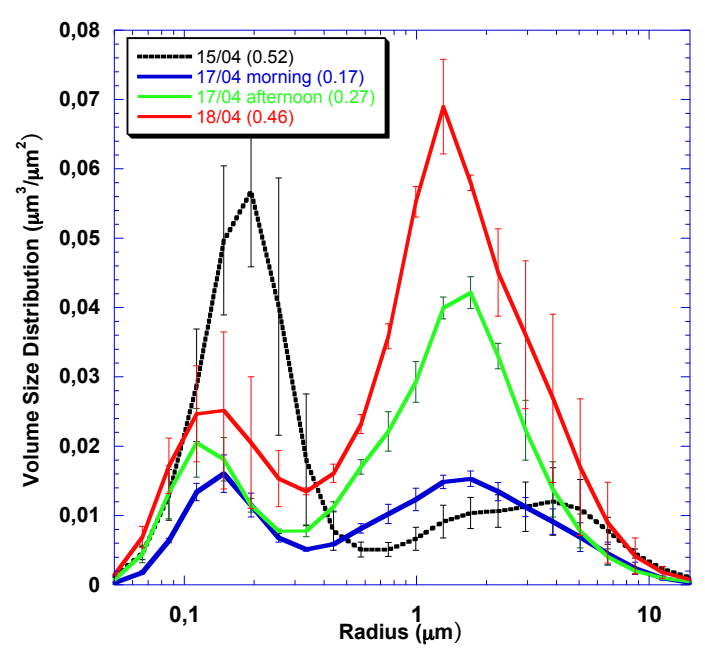

Fig. 3. Average size distributions (level 2) retrieved on 15,17 and 18 April 2010. Error bars represent standard deviation and indicate time variability.

April, in the afternoon, the average RI was $1.55 \pm 0.03$ at $440 \mathrm{~nm}$, which was consistent with an increase of silicate particles concentration within the atmospheric column. At $440 \mathrm{~nm}$ and $870 \mathrm{~nm}$, SSA was found to be $0.88 \pm 0.02$ and $0.93 \pm 0.02$, respectively. The first spectral derivative of SSA is negative, which is an indicator of a mineral dust signature (Dubovik et al., 2002b).

The contrast between 15 and 17 April is quite significant and larger than the expected uncertainty on these parameters of 0.03 . In all these cases, AOD values at $440 \mathrm{~nm}$ are always larger than 0.40; therefore, the accuracy of AERONET products is good (Dubovik et al., 2002b).

AERONET retrievals (APF and SSA) also allow the estimation of vertically averaged or effective LR. At $532 \mathrm{~nm}$ an average LR of $54 \mathrm{sr}$ has been determined for the afternoon of 17 April. Given the fact that AERONET provides total, fine- and coarse-mode phase functions, the coarse-mode
LR, which can be mostly attributed to volcanic ash particles, was found to be $47 \pm 10 \mathrm{sr}$ at $532 \mathrm{~nm}$. This value is in relatively good agreement with values derived from AERONET data for natural non-spherical coarse particles, such as desert dust, in climatologic studies 40-50 sr, (Catrall et al., 2005), $55 \mathrm{sr}$ (Schuster et al., 2012) and volcanic particles in case study, 42 sr, (Derimian et al., 2012). LR was also calculated from AERONET data for 15 April, and a value of $71 \mathrm{sr}$ was found. At the end of May, when the volcanic activity ceased and the atmosphere was clear of ash particles, LR values returned to their initial value of around $70 \mathrm{sr}$, again consistent with values reported for Lille by Catrall et al. (2005). Recent studies that are focusing on the Eyjafjallajökull eruption (Gross et al., 2010; Ansmann et al., 2011; Schumann et al., 2011; Wiegner et al., 2011; Mona et al., 2012; Derimian et al., 2012) provided values of $50 \pm 10 \mathrm{sr}$ for ash, which are in agreement with the AERONET estimates presented in this study. Thus, RI, SSA, and LR values are indicating a modification of the chemical composition in the column that can either be explained by aerosol physico-chemical transformations and/or by a possible intrusion of new aerosol particle types somewhere in the atmospheric column. This effective change in the chemical composition is consistent with an intrusion of natural particles such as mineral dust originating from Saharan regions (Dubovik et al., 2002b) or volcanic ash transported from the Iceland region (Derimian et al., 2012) and very likely partially composed of silicates. The history of air mass trajectories (Fig. 4) shows that for 15-18 April, the air masses were not originating from the south, but from the east and north for 15 April, and from the northwest (Iceland) on the following days. The assumption of desert origin is therefore not realistic here.

Later in May, as shown in Fig. 1, thanks to sun-photometer data, one can observe again such changes in aerosol properties, with similar trends of increasing coarse-mode concentration (maximum concentration for particle radii around 1.5-2 micrometers). The observed changes are again qualitatively consistent with an ash layer intrusion originating from 

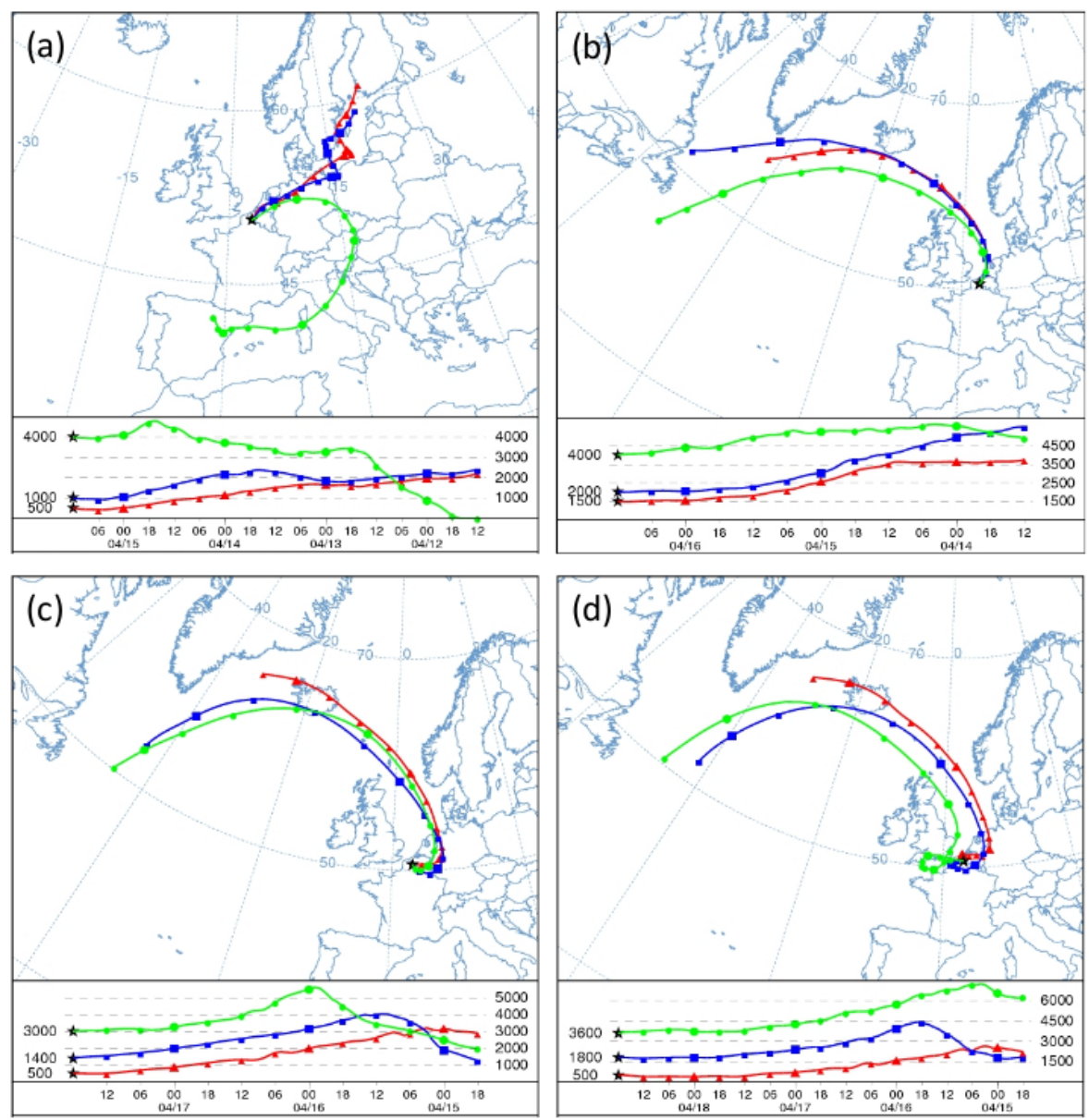

Fig. 4. Backward trajectories for 15 (a), 16 (b), 17 (c) and 18 (d) April 2010, ending at Lille (black star). The colors correspond to the different altitudes, given for each figure, below trajectories.

Iceland (confirmed by the backward-trajectory model). However, AOD remained mostly below 0.4 at $440 \mathrm{~nm}$ preventing the application of the quantitative analyses due to the decrease in the accuracy of the AERONET retrievals (Dubovik et al., 2002b).

In this part, aerosol columnar properties provided by sun photometer were described, exhibiting quite significant changes in April and May 2010. These changes affecting the atmospheric column (aerosol size, shape, refractive index, absorption) are consistent with successive volcanic ash plume intrusions, a claim confirmed by backwardtrajectories analysis showing that air masses passing over Lille originated from the Iceland region. However, information on aerosol vertical distribution that is not available from sun photometers is highly necessary to confirm and analyze in more detail these observations. Therefore, a combination of sun-photometer and lidar data will enable the derivation of aerosol vertical distribution and the estimation of their mass concentration.

\subsection{Lidar observations in Lille in April and May 2010}

Since 2006, LOA started aerosol/cloud observation with a micro-lidar operated $24 \mathrm{~h}$ per day and 7 days per week. Time series of lidar signal, as well as sun-photometer AOD and AE, are routinely published and available at http://www-loa.univ-lille1.fr/Instruments/LIDAR/. The processing system developed for data acquisition, transfer, and processing is applicable to any new site or even for a mobile lidar station (Mortier et al., 2012). The Cloud and Aerosol Micro Lidar (CAML) CE 370-2 developed by the CIMEL Company has already been described in the literature (Pelon et al., 2008; Leon et al., 2009). This eye-safe micropulse lidar system measures the radiation elastically backscattered from the atmosphere at $532 \mathrm{~nm}$, with power ranging from 50 to $130 \mathrm{~mW}$. Its principle is similar to most micropulse lidar systems (Welton et al., 2002); however, some differences allow for easier operation. The main difference is the emission and reception optical link from the rack to the telescope that is ensured by a $10 \mathrm{~m}$ optic fiber. Such a system can be placed 

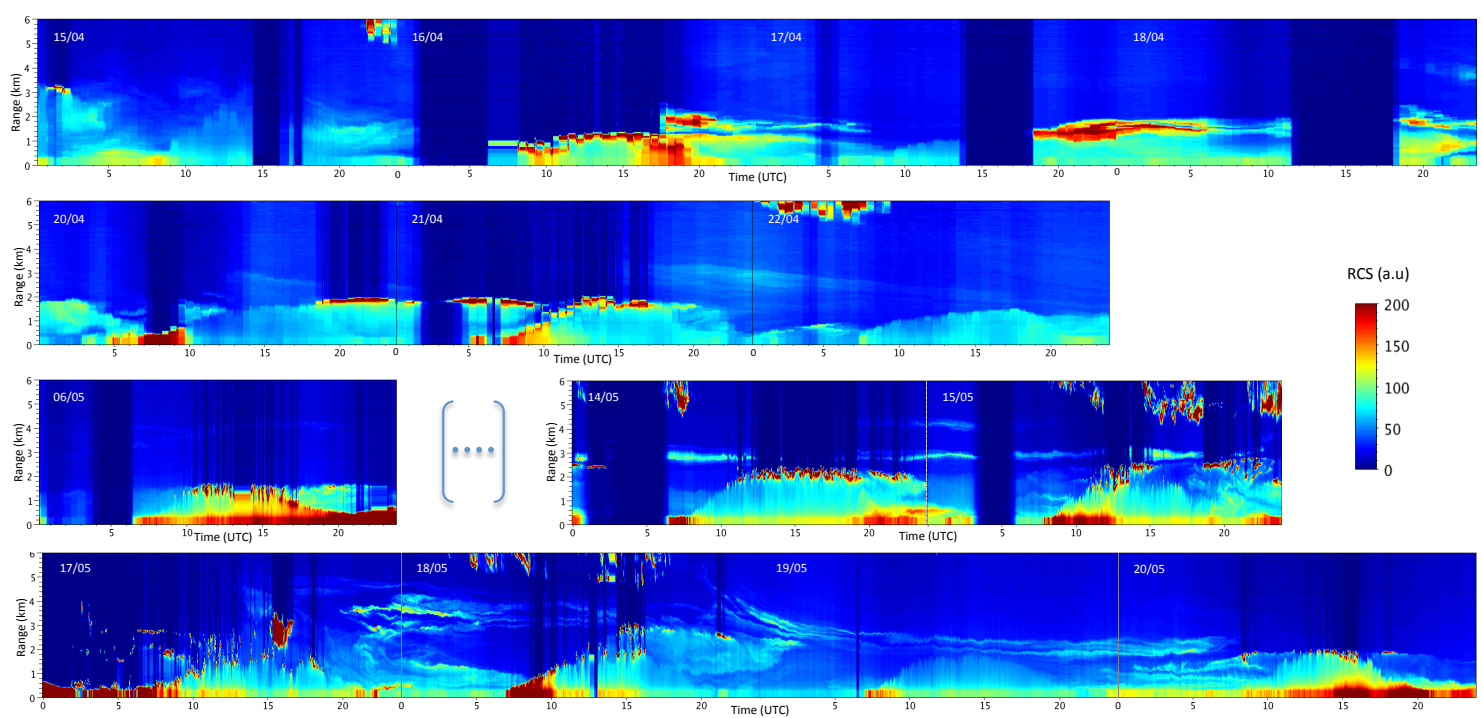

Fig. 5. Time series of lidar range corrected power $P(z)$ at $532 \mathrm{~nm}$ (maximum altitude considered is $6 \mathrm{~km}$ ). Blue brackets separate the two observing periods (from 15 April to 20 May 2010).

outside a small building where all the acquisition systems are located. Signal detection and processing is ensured by an avalanche photodiode, protected by an acousto-optic device deviating the received beam during laser emission, a photon counting system ( $30 \mathrm{~km}$ range, at $15 \mathrm{~m}$ resolution) and a summation processor. Due to the after-pulse phenomenon, no useful signal is detected from a distance below $240 \mathrm{~m}$ in the current version of the device. Measurements were made according to either a standard sequence of $10 \mathrm{~min}$ acquisition every half hour or in continuous mode. This system was in operation during the Eyjafjallajökull volcanic eruption. In Fig. 5, time series of lidar profiles showing ash-plume features, mainly located below $6 \mathrm{~km}$, over Lille in April and May 2010 are presented.

In the atmosphere, aerosol vertical distribution follows general patterns. In the planetary boundary layer roughly from 0 to $2 \mathrm{~km}$, aerosol spatial variability and lidar signal amplitude are high, whereas on the opposite, in the free troposphere ranging from 2 to $8 \mathrm{~km}$, aerosol spatial variability and lidar signal amplitude are low, except for the cases in which aerosol particles are transported from large distances such as biomass burning, desert dust or volcanic ash. Finally, the far field region of troposphere corresponding to altitudes about 8 to $10 \mathrm{~km}$, is generally very clean (Extinction $<4.10^{-3} \mathrm{~km}^{-1}$ at $550 \mathrm{~nm}$; Johnson et al., 2012b; Weitkamp, 2005) and is frequently used for selecting the reference altitude requested to calibrate lidar against the molecular atmosphere. Pictures presented in Fig. 5 show several complex aerosol features distributed over one or several layers from 15 to 22 April. Range corrected signals are given for the 0 to $6 \mathrm{~km}$ range in order to focus on the more relevant part of the troposphere for these two periods.
On 15 April, lidar was operating during night and daytime and revealed an almost cloud-free atmosphere, typical of a Lille background pollution situation. The weather conditions changed during the night, and low-level clouds were detected on 16 April at least up to 18:00 UTC. Then clouds disappeared and a layer was detected at about $2 \mathrm{~km}$. Both rangecorrected signal and geometrical thickness of this layer decreased with time until no more layers were detected between 08:00 and 14:00 UTC. Lidar operation stopped temporarily up to 18:00 UTC, and when restarted a very dense aerosol layer was detected at about $1.5 \mathrm{~km}$ and remained detectable up to 18 April around midnight. The maximum geometrical thickness of about $1 \mathrm{~km}$ was measured near 22:00 UTC and then decreased to reach its minimum at 07:00 UTC. The day after, 19 April, due to bad weather conditions, no data were available. Finally, thin layers of aerosols located between 2 and $3 \mathrm{~km}$ were still visible the three next days (20-22 April), when both low and high clouds were temporarily present in the atmosphere. In May the volcanic ash plume was first detected on 6 May, between 3 and $4 \mathrm{~km}$. It must be noted that due to maintenance, the laser source was changed (laser power at least doubled) and acquisition restarted after 5 May. Unfortunately, from 6 to 14 May, low level clouds and rain strongly restricted the number of sun-photometer observations. However, during some short temporal windows, lidar detected one or two separate aerosol layers at 3 and $4.5 \mathrm{~km}$ on 8 May, and one single layer located around $3.5 \mathrm{~km}$ on 9 May. On 14 May one aerosol layer was detected at $3 \mathrm{~km}$ in the morning, then a second one higher, at $4.2 \mathrm{~km}$, during the night - this layer being detected through the whole night up to 08:00 UTC on 15 May. Lidar also detected a complex aerosol pattern up to $5 \mathrm{~km}$ from noon to midnight on 15 May. The maximum of attenuated backscattered signal was 
located around $3.5 \mathrm{~km}$ during that period as well as during the first part of 18 May. On 19 May, one aerosol layer was detected around $2-3 \mathrm{~km}$, and remained detectable during day and night up to 07:00 UTC on 20 May. At the Lille site, 20 May was the last day volcanic ash was detected. This analysis has shown that information presented in Fig. 5 is consistent with sun-photometer observations reported in the previous section, due to the fact that detection of aerosol layers has confirmed in most cases the daytime detection performed from sun-photometer data. A quantitative analysis will be presented in the next section.

\section{Lidar/sun-photometer inversion}

In order to provide an estimate of ash mass concentration (AMC) from extinction profiles, which is our main objective, first we recall the lidar equation and describe the applied instrumental corrections. Then, the inversion methodology is described and uncertainty is evaluated. Among the available datasets, this study focuses on results obtained during the more significant time windows in April and May 2010.

\subsection{Methodology}

In this section we describe daytime lidar data processing in combination with sun-photometer AOD for retrieving aerosol extinction profile, $\sigma_{\mathrm{a}, \text { ext }}(z)$, and the effective extinction-to-backscatter ratio, or LR. The basis of the methodology is similar to that described by Léon et al. (2009). However, several improvements have been introduced both at instrumental (non-linearity of the detector, analysis of temperature sensitivity, noise filtering) and inversion levels (accounting for multilayer configurations relevant for this specific analysis).

At instrumental level, data processing includes several corrections such as background sky irradiance, non-linearity of the detector, overlap correction and after-pulse phenomenon (causing a blind zone below $z_{\min }=240 \mathrm{~m}$ for vertical sounding). The after-pulse signal is measured once a week and corrected using linear interpolation. The background "sky" irradiance is measured by averaging lidar signal at high altitude range (above $22 \mathrm{~km}$ ). The overlap function is determined using horizontal shots during clean and stable atmospheric conditions (Pelon et al., 2008). Finally, lidar profiles within 20 min were accumulated and signal-to-noise ratio improved by filtering range-corrected signals on the fast Fourier transform spectrum (high frequency reduction).

Once all the previous corrections applied, the lidar signal is only controlled by the atmospheric scattering and extinction processes as shown by Eq. (1), giving the rangecorrected attenuated backscattering signal,

$$
\begin{aligned}
& P(z)=K \cdot\left(\beta_{\mathrm{a}}(z)+\beta_{\mathrm{m}}(z)\right) \\
& \quad \exp \left(-2 \int_{z_{\text {min }}}^{z}\left(\sigma_{\mathrm{a}, \text { ext }}\left(z^{\prime}\right)+\sigma_{\mathrm{m}}\left(z^{\prime}\right)\right) \mathrm{d} z^{\prime}\right),
\end{aligned}
$$

with $\beta_{\mathrm{a}}$ and $\beta_{\mathrm{m}}$ as the backscattering coefficients for aerosol and molecules, respectively, and $\sigma_{\mathrm{a}, \text { ext }}$ and $\sigma_{\mathrm{m}}$ are the extinction coefficients for aerosols and molecules, respectively. The $K$ factor, a pure instrumental parameter, although subject to variation, is evaluated from the assumption that the backscatter coefficient is known for any reference altitude where inversion procedure starts. Usually, the reference altitude, $z_{\text {ref }}$, is taken in the far zone $(z>7 \mathrm{~km})$, where the signal can be mostly attributed to molecular scattering. In this situation, total backscatter coefficient $\beta_{\mathrm{a}}\left(z_{\text {ref }}\right)+\beta_{\mathrm{m}}\left(z_{\text {ref }}\right)$ is close to $\beta_{\mathrm{m}}\left(z_{\text {ref }}\right)$. The choice of reference altitude yields in a small additional error (Russel et al., 1979; Pueschel et al., 1994; Chazette et al., 2002).

The aerosol backscattering coefficient, $\beta_{\mathrm{a}}$, is linked (Eq. 2) to the aerosol single-scattering albedo (SSA or $\varpi_{\mathrm{o}}$ ) to the aerosol phase function in the backscattering direction, $\operatorname{APF}(\pi)$, and to the extinction coefficient, $\sigma_{\text {ext,a }}$. All of these parameters can change with the altitude.

$\beta_{\mathrm{a}}=\frac{\operatorname{SSA} \cdot \sigma_{\mathrm{ext}, \mathrm{a}} \cdot \operatorname{APF}(\pi)}{4 \pi}$

Hence, the introduction of the extinction-to-backscatter coefficient ratio, $\mathrm{LR}=\frac{\sigma_{\mathrm{a}} \text { ext }}{\beta_{\mathrm{a}}}$, also called lidar ratio, yields Eq. (3),

$$
\begin{aligned}
& P(z)=K \cdot\left(\frac{\sigma_{\mathrm{a}, \mathrm{ext}}(z)}{\mathrm{LR}}+\beta_{\mathrm{m}}(z)\right) \\
& \quad \exp \left(-2 \int_{z_{\min }}^{z}\left(\sigma_{\mathrm{a}, \text { ext }}\left(z^{\prime}\right)+\sigma_{\mathrm{m}}\left(z^{\prime}\right)\right) \mathrm{d} z^{\prime}\right) .
\end{aligned}
$$

Once calibrated against molecular scattering in the reference zone, one equation with two unknown variables (LR and $\sigma_{\text {ext,a }}$ ) remains, thus yielding an underdetermined equation. Retrieval of $\sigma_{\text {ext,a }}$ profile and effective LR are performed during daytime using the same methodology as used by Leon (2009), based on the Klett and Fernald solution (1981, 1984) including the use of accurate AOD measurements (AERONET $\triangle \mathrm{AOD}=0.01$ ) as a constraint to retrieve LR. As previously mentioned, due to the after-pulse phenomenon, the atmospheric layer below $z_{\min } \approx 240 \mathrm{~m}$ (in case of vertical sounding) cannot be sampled by the system used in this study. The result is therefore slightly biased (Pelon et al., 2008; Leon et al., 2009) due to a small systematic difference between lidar and sun-photometer AOD. This was partially accounted for by assuming as constant the lidar range corrected signal from $250 \mathrm{~m}$ to ground level.

A more accurate retrieval of the extinction profile would be possible if the atmosphere were vertically homogeneous in terms of the optical properties aerosols (e.g., 
$1 / \mathrm{LR} \propto \operatorname{SSA} \cdot \operatorname{APF}(\pi) \approx$ constant). In Leon et al. (2009), retrievals are performed assuming that the planetary boundary plus the free troposphere layers can be described by a single LR (effective value). Regarding uncertainty, one of its main sources in the retrievals is generated by the unknown vertical variation of LR. In the present study, this approach is improved by considering, when relevant, a more realistic description obtained by combining two homogeneous layers characterized by their own $L R, L_{A L}$ for the ash layer (AL) and $\mathrm{LR}_{\mathrm{PBL}}$ for the boundary layer and anywhere else. Of course, both of them cannot be retrieved at the same time, and one has to therefore be set a priori by using additional information (climatologic value from either lidar or AERONET, in situ, etc.). Although simple, this description improves the retrieval of vertical profiles in the case of multiple layers. As expected, other sources of uncertainty are the following: (i) the reference signal $P\left(z_{\text {ref }}\right)$, which affects the value of LR and consequently the extinction; (ii) the error in the overlap function (primary source of error in the bottom layer, error is close to $10 \%$ above $600 \mathrm{~m}$, whereas error reaches $50 \%$ near the surface, Leon et al., 2009); and (iii) a bias introduced in the extinction profile by the blind zone. The uncertainty assessment given by Leon et al. (2009) has been refined considering a vertical distribution of aerosol particles and represented now by $L_{\mathrm{PBL}}$ and $\mathrm{LR}_{\mathrm{AL}}$. Based on the inversion of a representative set of synthetic lidar profiles, the uncertainty of both the retrievals of extinction profile and LR in the PBL (respectively in the ash layer) for a given value of the LR in the AL (respectively in the PBL) was assessed. Results show that, due to the maximum uncertainty on the overlap in the bottom part of the PBL, both the extinction profile and LR in the $\mathrm{AL}$ are less accurately retrieved (20-25\% on extinction) when LR is fixed in the PBL. Conversely, and for the same reason, when the $\mathrm{LR}_{\mathrm{AL}}$ is fixed, extinction profile is more accurately retrieved $(15 \%)$. Our analysis strategy results directly from the previous conclusions. Remembering that the primary goal is to derive AMC with the best possible accuracy, one has to minimize the uncertainty on the retrieved extinction profiles, especially in the AL.

Assuming that in the early stages of the volcanic ash intrusion, the PBL was not significantly affected by the ash particles, and therefore one can reliably retrieve $L_{A L}$ by using for $L_{\mathrm{PBL}}$ a value of $70 \pm 8 \mathrm{sr}$ that was obtained on 15 April 2010. This LR value is close to the climatologic value for Lille, as published by Catrall et al. (2005) and is also very close to the AERONET-derived value for the same day $(71 \mathrm{sr})$. This value has been used to derive $\mathrm{LR}_{\mathrm{AL}}$ from lidar observations performed on 17 April during the first appearance of volcanic ash above the Lille region. The derived value was $48 \mathrm{sr}$, which is identical to what was derived using AERONET observations for Lille (regarding the only coarse mode of the VSD) at the same day (Derimian et al., 2012) and also close to several lidar-derived values for ash in other locations, e.g., 50 sr for 18 April in Paris (Chazette et al., 2012),
$55 \mathrm{sr}$ in Munich, Germany (Ansmann et al., 2011), and $50 \mathrm{sr}$ in Italy (Mona et al., 2012).

Accounting for the uncertainty on the $\mathrm{LR}_{\mathrm{PBL}}, \mathrm{LR}_{\mathrm{AL}}$ and its uncertainty are estimated at $48 \pm 10 \mathrm{sr}$. All extinction profiles considered in the following analysis were obtained using AERONET AOD and the retrieved value of $\mathrm{LR}_{\mathrm{AL}}(48 \mathrm{sr})$, taking into account its uncertainty $(10 \mathrm{sr})$.

\subsection{Results}

For the more relevant time windows -17 and 18 April, and 6 to 19 May - in Figs. 6 and 7 extinction profiles and corresponding backward trajectories are presented. As explained previously, in order to minimize the impact of the overlap uncertainty, and to provide a more accurate determination of the extinction profile, in the following section all lidar data were inverted with $\mathrm{LR}_{\mathrm{AL}}=48 \mathrm{sr}$. Moreover, in order to assess dynamically the uncertainty on the extinction coefficient, each inversion was performed (i) for a set of overlap correction functions known as being representative of the experimental limits observed, (ii) with instrument noise, and (iii) accounting for the uncertainty on $\mathrm{LR}_{\mathrm{AL}}$. Figures 6 and 7 show either single or multiple layers being detected and tracked by the lidar system and the fact that their corresponding air masses were coming from the Iceland region. The areas shaded in dark color show the uncertainty due to overlap error, light shaded areas show the uncertainty due to noise, and dashed lines include the two previous plus the uncertainty on $\mathrm{LR}_{\mathrm{AL}}$. Since the origin of an air mass can be analyzed from back trajectories, and given the fact that the lidar system used cannot measure the depolarization ratio that gives information on aerosol shape (spherical/non-spherical), the current approach to validate the volcanic origin of the aerosols detected is based on the analysis of back trajectories and AERONET NSF, which also confirms the presence of non-spherical particles in the atmospheric column. Over the Lille region, the extinction peaks were measured during daytime, with values reaching $0.35 \mathrm{~km}^{-1}$ on 17 April at $1.1 \mathrm{~km}$, and $0.65 \mathrm{~km}^{-1}$ on 18 April at $1.7 \mathrm{~km}$ (Table 1). The extinction coefficient is known with an uncertainty of about $20 \%$. In all cases, as shown by backward trajectories presented in Figs. 6 and 7, aerosol layers detected in the free troposphere were originating from the Iceland region. During their transport, aerosol particles may have encountered various humidity conditions; therefore, the scattering properties of the aerosols are subjected to considerable apparent variability due to the possible uptake of water. Lidar-derived profiles of the extinction coefficient are therefore affected by variable and generally unknown amounts of humidity. According to the literature (Randriamiarisoa et al., 2006), the effect of humidity, described by relative humidity ( $\mathrm{RH})$, is rather constant up to $70 \%$, but the scattering coefficient can double when RH reaches $90 \%$ for urban aerosols. Using the ground-based RH and a standard atmospheric model, it was estimated, within the range of altitudes where extinction peaks reached their 

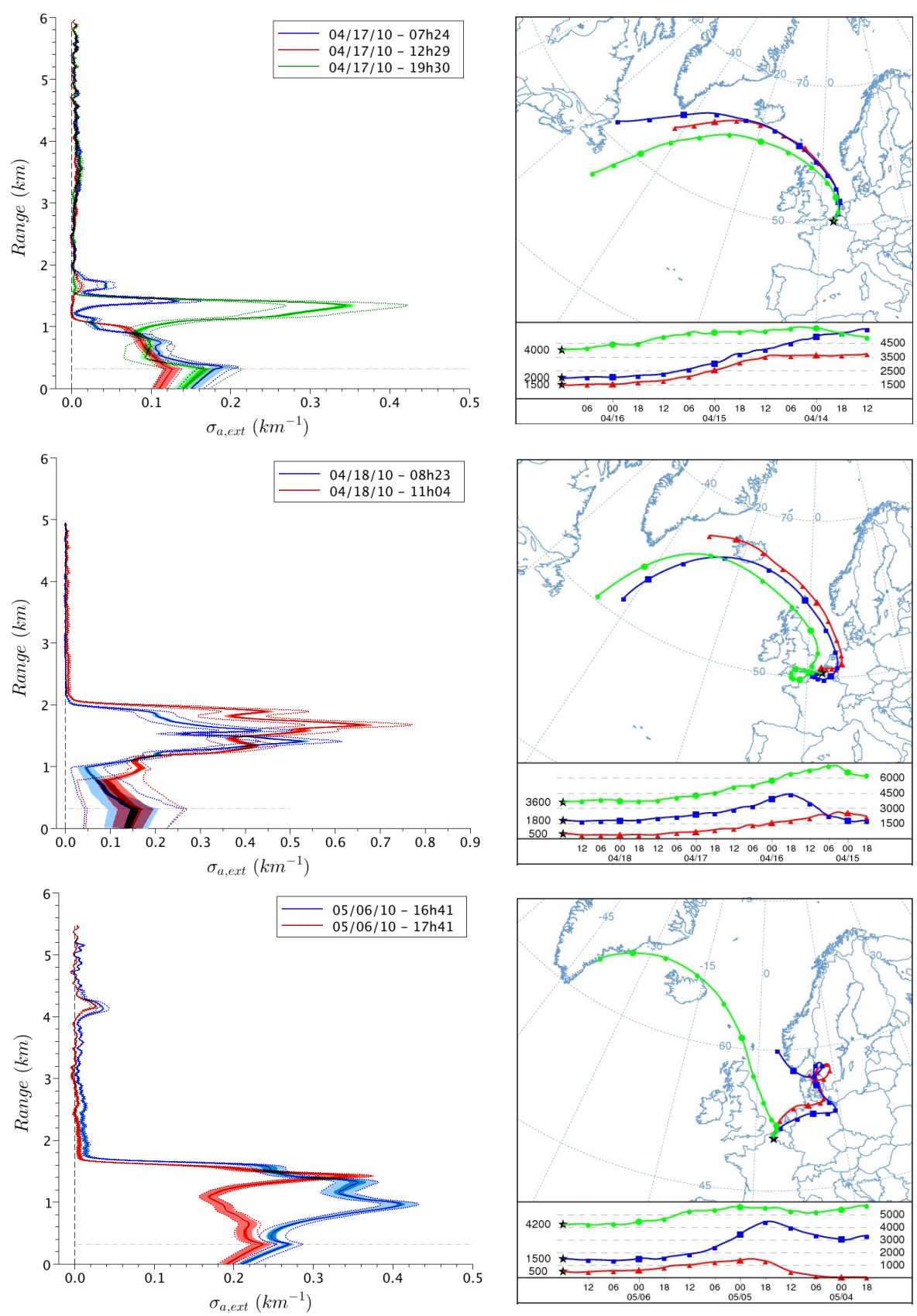

Fig. 6. Retrieved extinction profiles and corresponding backward trajectories for 17, 18 April and 6 May 2010. Colored areas on extinction profiles correspond to uncertainties (light: overlap, dark: noise). Dotted lines are extinction profiles retrieved taking into account the input LR $_{\text {ASH }}$ uncertainty $(10 \mathrm{sr})$.

maximum $(2-3 \mathrm{~km})$, that the positive bias due to humidity could reach up to $50 \%$ in the case of urban aerosols. Ash being less hygroscopic than urban aerosols, as well as dust (Kaaden et al., 2008), the bias, although difficult to estimate, could be therefore much less important.

Sun-photometer AOD (total column AOD) and lidarderived AOD (for ash layer only) are presented in Table 1. During daytime, the highest ash AOD of $0.37 \pm 0.07$ was measured on 18 April and the minimum detectable one of about 0.004 in May. As mentioned in the previous section, the sun-photometer AOD on 17 April exhibited a strong diurnal contrast from morning to afternoon, when successive volcanic plumes arrived over the region. For 17 April the sun-photometer AOD variation at $532 \mathrm{~nm}$ of 0.12 (AOD difference between afternoon (0.24) and morning (0.12) AOD) is a direct and accurate measure of ash AOD. At the same 

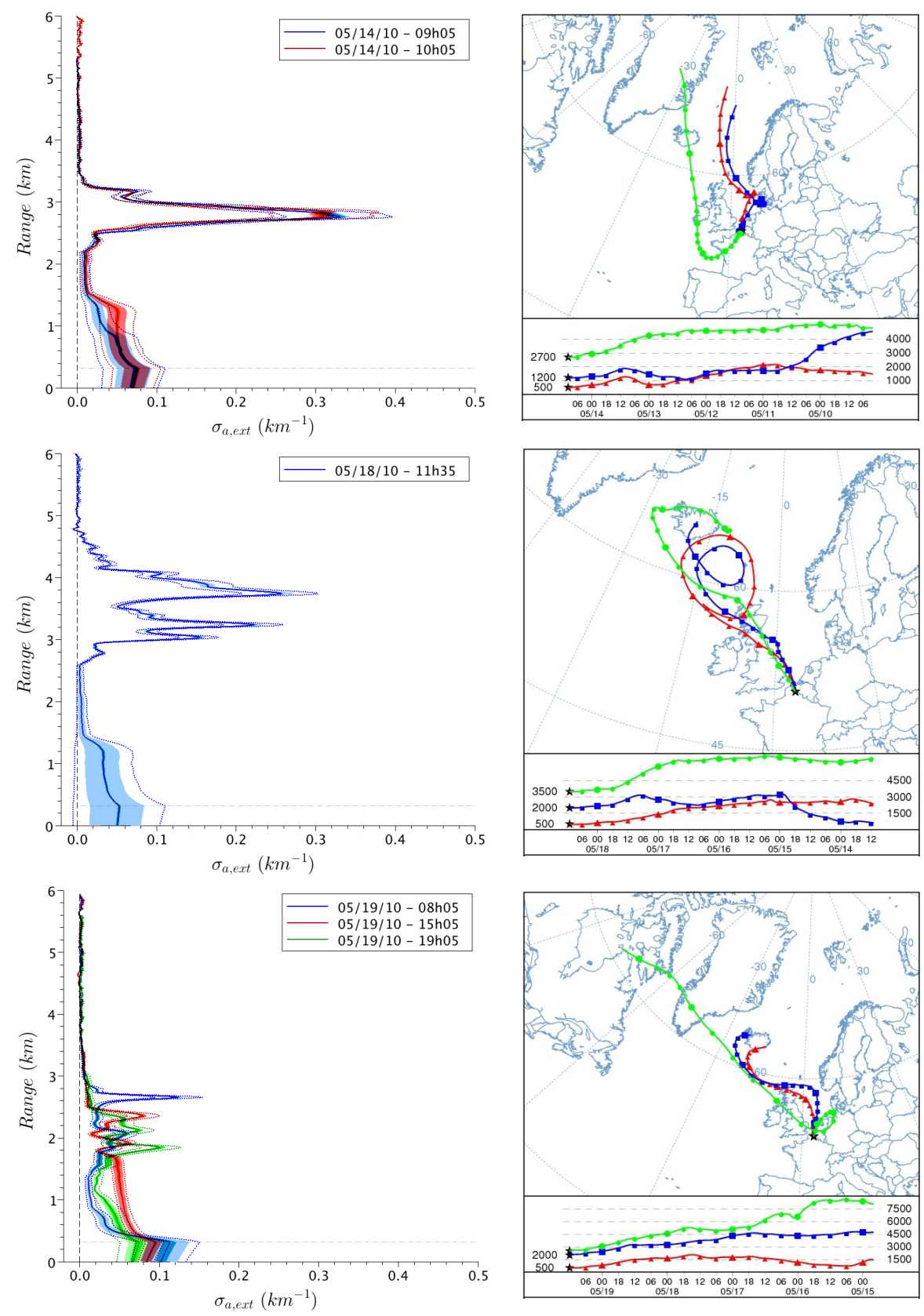

Fig. 7. Retrieved extinction profiles and corresponding backward trajectories for 14, 18, and 19 May 2010.

time, the lidar-derived AOD of $0.12 \pm 0.02$ for the ash is in perfect agreement with the value derived from sun photometer. Similar results were obtained for 18 April, when a strong AOD variation was also observed due to overpass the ash layers. Results provide $0.13 \pm 0.01$ and $0.14 \pm 0.05$ for sunphotometer and lidar-derived AODs, respectively.

\section{Lidar/sun-photometer-derived aerosol mass concentration}

For aviation safety and for modeling purposes, the main goal is to estimate AMC, this value and its uncertainty being extremely relevant for the risk assessment on aircraft engines.

According to the British Civil Aviation Authority, 2012, based on the Met Office's Volcanic Ash Advisory Centre (http://www.metoffice.gov.uk/aviation/vaac/) simulation data, the following thresholds have been established following the 2010 Eyjafjallajökull eruption: 
Table 1. Summary of the main characteristics of volcanic ash layers detected over Lille. The range of the layer, extinction $\sigma_{\mathrm{a}}$, ext, its uncertainty $\Delta \sigma_{\mathrm{a}}$, ext, and AMC estimation are given for the relative maximum concentration detected in the profile. $\tau$ and $\tau_{\text {ash }}$ are, respectively, aerosol optical depth for the total atmospheric column and ash layer.

\begin{tabular}{cccccccc}
\hline Date & Time $(\mathrm{UTC})$ & Range $(\mathrm{m})$ & $\sigma_{\mathrm{a}, \text { ext }}\left(\mathrm{km}^{-1}\right)$ & $\Delta \sigma_{\mathrm{a}, \text { ext }}\left(\mathrm{km}^{-1}\right)$ & $\tau$ & $\tau_{\mathrm{ash}}$ & ${\mathrm{AMC}\left(\mu \mathrm{g} \mathrm{m}^{-3}\right)}$ \\
\hline $17 / 04$ & 07.00 & 1410 & 0.132 & 0.026 & 0.180 & 0.030 & 214 \\
$17 / 04$ & 12.00 & 1650 & 0.013 & 0.003 & 0.125 & 0.004 & 21 \\
$17 / 04$ & 19.00 & 1100 & 0.344 & 0.069 & 0.250 & 0.121 & 558 \\
$18 / 04$ & 08.00 & 1440 & 0.526 & 0.105 & 0.370 & 0.238 & 854 \\
$18 / 04$ & 11.00 & 1680 & 0.654 & 0.131 & 0.530 & 0.376 & 1061 \\
$06 / 05$ & 16.75 & 4125 & 0.036 & 0.007 & 0.520 & 0.010 & 58 \\
$06 / 05$ & 17.75 & 4170 & 0.028 & 0.006 & 0.360 & 0.006 & 45 \\
$14 / 05$ & 09.00 & 2760 & 0.330 & 0.066 & 0.200 & 0.114 & 536 \\
$14 / 05$ & 10.00 & 2820 & 0.313 & 0.063 & 0.210 & 0.106 & 508 \\
$15 / 05$ & 06.75 & 2895 & 0.253 & 0.051 & 0.330 & 0.100 & 411 \\
$17 / 05$ & 14.60 & 3555 & 0.110 & 0.022 & 0.230 & 0.121 & 179 \\
$18 / 05$ & 11.50 & 3720 & 0.260 & 0.052 & 0.230 & 0.165 & 422 \\
$19 / 05$ & 08.00 & 2655 & 0.124 & 0.025 & 0.120 & 0.044 & 201 \\
$19 / 05$ & 15.00 & 2355 & 0.080 & 0.016 & 0.150 & 0.020 & 130 \\
$19 / 05$ & 19.00 & 1845 & 0.101 & 0.020 & 0.130 & 0.051 & 164 \\
$20 / 05$ & 05.00 & 2205 & 0.154 & 0.031 & 0.185 & 0.118 & 250 \\
\hline
\end{tabular}

- low density: airspace with volcanic ash concentrations equal to or less than $2000 \mu \mathrm{g} \mathrm{m}^{-3}$;

- medium density: airspace with volcanic ash concentrations ranging between 2000 and $4000 \mu \mathrm{g} \mathrm{m}^{-3}$;

- high density: airspace with volcanic ash concentrations equal to or greater than $4000 \mu \mathrm{g} \mathrm{m}^{-3}$.

Since the amount of information provided by the micro-lidar system is not self-sufficient, the determination of AMC from the lidar-derived extinction coefficient within the ash layer requires in general some knowledge/assumptions on the ash VSD as well as on the mass density of the ash particles. The methodology and AMC peak values estimated for a selection of dates in April and May are presented in the following sections.

\subsection{Methodology}

This section focuses on relating optical extinction derived from remote sensing retrievals based on lidar and sun photometer to the AMC. The specific extinction coefficient is a parameter of particular interest in this case since AMC estimates can be derived from the extinction coefficient by applying an agreed value of the volcanic ash specific extinction. Existing estimates of the specific extinction for volcanic ash are ranging from $0.5 \mathrm{~m}^{2} \mathrm{~g}^{-1}$ to $1.1 \mathrm{~m}^{2} \mathrm{~g}^{-1}$ (Ansmann et al., 2010; Johnson et al., 2012a). In the present work an alternative approach is considered, given the fact that aerosol microphysical properties are available from AERONET data (version 2, Level 2), specifically the VSD that is linked to number size distribution, $n(r)$, RI, and NSF. The uncertainty on AMC is therefore mainly driven by the uncertainty of the lidar-derived extinction profiles, aerosol density, size distribution and RI. For the sake of simplicity, the cross section $\pi r^{2} Q_{\text {ext }}$ for spherical particles was computed using Mie theory in order to link lidar-derived extinction coefficient $\sigma_{\mathrm{a} \text {,ext }}$ to the size distribution available from AERONET (Eq. 4),

$\sigma_{\mathrm{a}, \mathrm{ext}}(z, \lambda)=\int_{r_{\min }}^{r_{\max }} \pi r^{2} Q_{\mathrm{ext}}(r, m, \lambda) \cdot n(r, z) \mathrm{d} r$.

In Eq. (4) the size distribution $n(r, z)$ at any altitude $z$, is, under certain assumptions, simply linked to ash volume concentration and, given the particle density, to the mass concentration AMC $\left(\mu \mathrm{g} \mathrm{m}^{-3}\right)$. For the ash VSD this paper considers, as described by Derimian et al. (2012), the VSD computed from the difference between afternoon and morning size distribution for 17 April (Fig. 3). Since the ash VSD was mostly dominated by coarse-mode particles, VSD was described by a mono-modal log-normal distribution with three parameters, $r_{\mathrm{mc}}, \sigma_{\mathrm{c}}$ and $N_{\mathrm{c}}-$ modal radius, width and number concentration $\left(\mathrm{m}^{-3}\right)$, respectively. The complex RI retrieved from AERONET inversions of $1.55-0.01 i$ was used. The shape $\left(r_{\mathrm{mc}}, \sigma_{\mathrm{c}}\right)$ of the size distribution is fixed $\left(r_{\mathrm{mc}}=1.5 \mu \mathrm{m}\right.$ with a standard deviation of $\sigma_{\mathrm{c}}=0.7$ ), as given by AERONET inversions for the evening of 17 April. By dividing this VSD into $n(r)=n_{0} n_{1}(r)$, where $n_{1}$ is the normalized VSD and $n_{0}$ the amplitude, and using a density of particles $(\rho)$, one can retrieve the $\mathrm{AMC}$ as follows:

$\mathrm{AMC}=\frac{4}{3} \sigma_{\mathrm{a}, \mathrm{ext}} \int_{r_{\min }}^{r_{\max }} \frac{\rho(r) \cdot r^{3} n_{1}(r)}{\int_{r_{\min }}^{r_{\max }} Q_{\mathrm{ext}}(m, r, \lambda) \cdot n_{1}(r) \cdot r^{2} \mathrm{~d} r} \mathrm{~d} r$.

The uncertainty on the shape of VSD is difficult to assess (Dubovik et al., 2002b); however, an estimate can 
Table 2. Uncertainty sources and relative impact on AMC estimation. The extinction uncertainty contains both instrumental (overlap, noise, etc.) and inversion method (lidar ratio, reference altitude) errors. The total error on AMC is calculated in case of independent error sources.

\begin{tabular}{lrr}
\hline Source & Uncertainty & Impact on AMC \\
\hline$r_{\mathrm{mc}}$ & $15 \%$ & $20 \%$ \\
$\sigma_{\mathrm{c}}$ & $10 \%$ & $8 \%$ \\
$\mathrm{RI}$ & 0.05 & $<2 \%$ \\
density & $20 \%$ & $20 \%$ \\
shape & - & $<10 \%$ \\
$\sigma_{\mathrm{a}, \mathrm{ext}}$ & $20 \%$ & $20 \%$ \\
\hline Total & - & $40 \%$ \\
\hline
\end{tabular}

be obtained from the variability of these parameters using AERONET inversions available for 18 April. Variability on the modal radius is found to be around $15 \%$, thus yielding around $20 \%$ variability on the AMC, whereas the observed $10 \%$ variability of the width of the size distribution yields a variability of $8 \%$ on the AMC. An estimation of the impact of an absolute error of 0.05 on RI when computing AMC was found to be of about $1-2 \%$.

The conversion from number size distribution or volume size distribution to AMC requires an estimation of aerosol density. In the case of volcanic ash, a realistic value for aerosol density ranges between 0.7 to $3 \mathrm{~g} \mathrm{~cm}^{-3}$ (http: //volcanoes.usgs.gov/ash/properties.html). The mass density mainly depends on the morphology and composition of aerosols. However, for its conversion to mass concentration, as many authors did (Schumann et al., 2011; Ansmann et al., 2011), the value of $2.6 \mathrm{~g} \mathrm{~cm}^{-3}$ has been considered in the present calculations. Density also depends on porosity of particles, which is not a very well known factor. Based on the recent literature (Ansmann et al., 2011), an uncertainty of $0.5 \mathrm{~g} \mathrm{~cm}^{-3}$ or $20 \%$ is assumed. Additionally, we evaluated the bias introduced by assuming spherical particles in Eq. (4) instead of non-spherical particles in the current approach. The AMC has been estimated from the extinction coefficient with a VSD for spherical particles model in one case and non-spherical particles model in the other case. The shape difference biases by less than $10 \%$ the AMC estimate, considered acceptable, regarding other error sources such as assumption on density. Assuming these errors to be independent, a root sum of squares approach gives an overall uncertainty of $40 \%$. Given that uncertainties related to the RI, shape, and density could be interlinked, the worst case error can be of about $60 \%$. Therefore, according to the results of this study, one can state that a reasonable estimate regarding the overall average uncertainty is close to $50 \%$. The different uncertainty sources and the total error estimation are summarized in Table 2.
Finally, the interpretation of apparent ash extinction in terms of mass is complicated by the uncertainty on atmospheric humidity. The water on ash particles amplifies the scattering signal, which can yield a large overestimate of the derived mass of about $50 \%$.

In the present analysis, ash properties (VSD, RI, LR) are assumed to have remained constant during April and May 2010. Some authors (Schuman et al., 2011) pointed out that in May, volcanic ash (sulfate-ash mixture) very likely had different properties than in April (mostly ash, sulfate being formed a few days later. The AERONET size distribution retrieved for 19 May and the morning of 20 May also exhibits a large coarse mode (centered around 1.5-1.7 $\mu \mathrm{m}$ ) and lower RI around 1.50 - a value more consistent with additional sulfate contribution. However, since the contribution of volcanic aerosol was becoming low (AOD equals 0.25 or less at $440 \mathrm{~nm}$ ), AERONET parameters were less accurate and could not be used for the AMC estimate.

\subsection{Results}

In this section the main characteristics of the ash plumes tracked over Lille are presented. The estimates of AMC (Table 1) provide a reasonably accurate indicator of the difference between AMC and the $2000 \mu \mathrm{g} \mathrm{m}^{-3}$ hazard threshold used by aviation. AMC are estimated during daytime due to the obvious limitation of the sun-photometer/lidar combination. Results summarized in Table 1 show that the highest concentration peaks were estimated for 17/18 April, with values reaching about $1000 \mathrm{\mu g} \mathrm{m}^{-3}( \pm 50 \%)$, whereas in May the AMCs were found to be generally lower (maximum of about $550 \mu \mathrm{g} \mathrm{m}^{-3}$ ). After 20 May no more ash was detected due to the significant decrease of eruptive activity.

Although ash retrievals were first performed only during daytime, Fig. 5 shows that during nighttime, the ash AMC was certainly higher on 17 April around 23:00 UTC. An estimate of AMC during nighttime has therefore been performed and is detailed below. In Sect. 3 we described how the sunphotometer AOD is used to retrieve the extinction profiles and LR during the daytime processing. However, since no sun-photometer data are available during nighttime, a prescribed LR for ash $\left(\mathrm{LR}_{\mathrm{AL}}=48 \mathrm{sr}\right)$ and LR for boundary layer $\left(L_{\mathrm{PBL}}\right)$ have been used to derive extinction profiles during nighttime. In order to minimize the impact of this a priori assumption, the last $\mathrm{LR}_{\mathrm{PBL}}$ retrieved using the AERONET AODs from the evening and the first $\mathrm{LR}_{\mathrm{PBL}}$ from the morning were used. These assumptions remain reasonably valid when there is no significant change in the aerosol properties between the two inversion times (daytime and nighttime, as considered here). Usually, the AERONET AOD measurements are available a short time before (after) sunset (sunrise). Therefore, this approach allowed the derivation of AOD during nighttime through the vertical integration of extinction coefficient provided by lidar. Good matching values of the lidar-derived AOD before and after midnight (based on 
last and first AERONET AOD from two successive days) can be used as an indicator of the approach's validity. According to these results (Fig. 8a), the continuity criterion on AOD was well satisfied for observations on the 17 and 18 April. The AOD peak reached a value of 0.55 at $532 \mathrm{~nm}$, observed at 23:00 UTC, representing more than double the daytime maximum AOD (0.27). All nighttime extinction profiles were inverted to estimate AMC. Figure $8 \mathrm{~b}$ shows a 2-D picture of AMC obtained from accumulation of all inverted profiles from 16 to the 18 April. More precisely, for atmospheric layers higher than $1.5 \mathrm{~km}$ and affected by volcanic ash, the coarse mode described in the previous section for converting extinction to AMC was considered, while for altitudes below $1.5 \mathrm{~km}$, only fine-mode particles with urban pollution aerosol density $(1.7 \mathrm{~g} \mathrm{~cm}-3)$ were considered (Sloane, 1984; Royer et al., 2011).

Nighttime AODs of 17 April show a quite strong gradient within a couple of hours around the ash peak ( 0.5 for AOD). After midnight (morning of 18 April) the ash layer rapidly became less dense, with AOD values reaching 0.4 just before sunrise, but still being about 2 times higher than on 17 April at sunrise. It can be noticed (not shown in Fig. 8) that on 17 April before sunset and on 18 April after sunrise, AE remained very similar (0.7), which is very consistent with the assumption that aerosol properties did not vary strongly during the night. This estimate is certainly less accurate during nighttime because of assumptions made on the LR profile. However, day/night AOD continuity is good and therefore demonstrates the quality of the results and the validity of this approach.

On 14 May a high AMC value was estimated for the early morning. According to Fig. 5, similar peaks of concentration might also have been present on 15 May in the afternoon. However, cloud layers prevented joint sun-photometer/lidar inversions.

On 18 May a high AMC close to $420 \mu \mathrm{g} \mathrm{m}^{-3}$ was estimated for the morning (11:30 UTC) at $3.7 \mathrm{~km}$, corresponding to an extinction coefficient close to $0.26 \mathrm{~km}^{-1}$ (Table 1 and Fig. 7). The extinction profile for 18 May is presented in Fig. 7 and shows an ash plume at $3 \mathrm{~km}$ height with an extinction peak close to $0.15 \mathrm{~km}^{-1}$ which has an equivalent AMC of $240 \mu \mathrm{g} \mathrm{m}^{-3}$ ( $\pm 50 \%$ ). Weber et al., (2012) reported measurements of PM10 concentrations (airborne in situ measurements) reaching $260 \mathrm{\mu g} \mathrm{m}^{-3}$ at the same altitude, the measurements being performed near the Dutch-German border, for the same time frame. Even though the distance to Lille was about $250 \mathrm{~km}$, the North of France, Belgium, The Netherlands and Germany were areas where Met Office forecasts predicted that volcanic ash might be encountered in concentrations larger than $200 \mathrm{\mu g} \mathrm{m}^{-3}$. Therefore, the estimates presented in this study can be considered as quite consistent with in situ measurements.

Figure 9 presents a picture taken during a regional flight with a small aircraft over the Lille region on 19 May. The grey ash layer can be seen very clearly. For that day the esti-

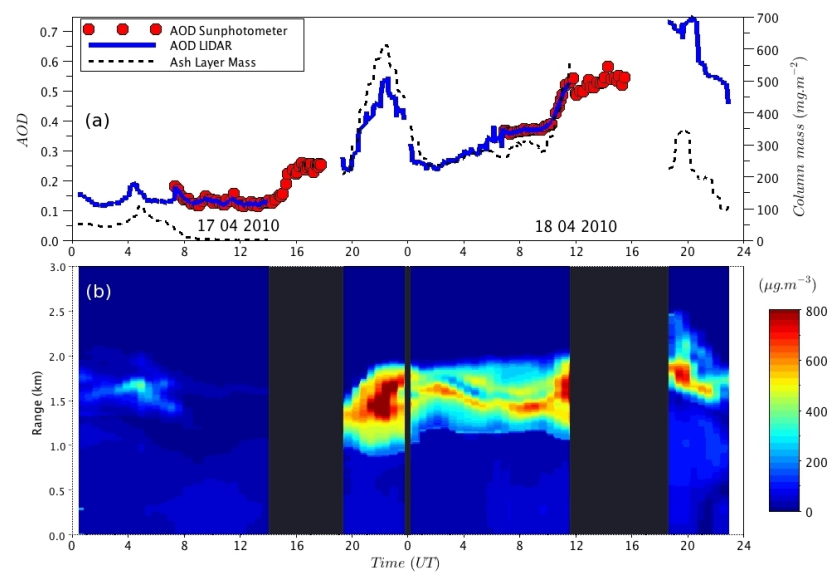

Fig. 8. Time series of (b) AMC and (a) lidar-retrieved AOD at 532 $\mathrm{nm}$ (in blue line), AERONET AOD at $532 \mathrm{~nm}$ (in red) and integrated mass in $\mathrm{mg} \mathrm{m}^{-3}$ (in black dash line) over Lille from 17 to 18 April 2010 .

mate of AMC for the morning after sunrise (08:00 UTC) gave a value of $200 \mu \mathrm{g} \mathrm{m}^{-3}$ (Table 1). According to our observations, after 20 May 2010 no more volcanic ash was detected.

\section{Conclusions}

Thanks to routine daytime lidar and sun-photometer observations and nighttime lidar observations, several volcanic ash plumes have been tracked over Lille during Eyjafjallajökull's eruptive period. The present analysis shows that during at least 22 days, atmospheric layers originating from Iceland and detected over Lille region exhibited variable ash concentrations that were estimated up to a maximum of $1000 \mathrm{\mu g} \mathrm{m}^{-3}$ (uncertainty $50 \%$ ) at the beginning of the period. However, high concentrations were measured on the night of 17 April, but remained below the $2000 \mathrm{\mu g} \mathrm{m}^{-3}$ aviation hazard limit.

The work presented firstly demonstrated that intrusions of non-spherical particles, mostly affecting the coarse-mode part of the VSD, were observed from Lille AERONET data. The analysis of the retrieved AERONET VSD shows an increase of the coarse-mode concentration for particle radius to around $1.5-2 \mu \mathrm{m}$. The real part of RI also increased from 1.46 to 1.55 , providing confirmation of change in the atmospheric column. Secondly, thanks to lidar/sun-photometer joint inversion, AMC over Lille has been derived and results show that AMC never exceeded the air traffic hazard limit $\left(2000 \mu \mathrm{g} \mathrm{m}^{-3}\right)$ in Lille. This study contributes to demonstrating the relevance of such observation systems for aerosol monitoring and characterization, especially in such hazardous situations. The monitoring and processing system developed by LOA provides now, in a routine manner, nearreal-time (NRT) aerosol extinction profiles as well as effective LR. Following the Eyjafjallajökull volcanic eruption, the 


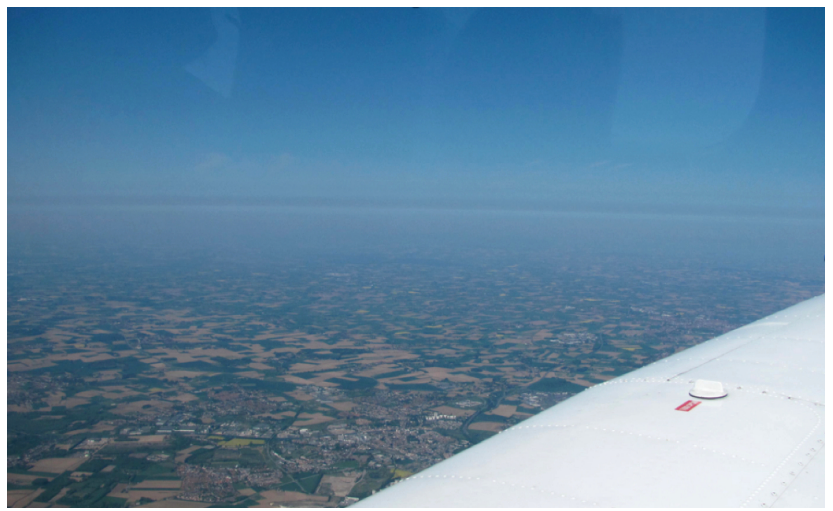

Fig. 9. Volcanic ash layer (grey layer in the horizon direction) at around $2.5 \mathrm{~km}$ altitude and close to Lille city, 19 May 2010 (courtesy from Y. Karol and C. Verwaerde, LOA).

processing system was implemented and provides more detailed information. The concept of the processing system developed can be the basis of network composed of sun/sky photometers and CIMEL or similar automatic micro-lidars. Moreover, in the future, night lidar observations can be completed by AOD measured by moon photometer recently developed by CIMEL and currently undervalidation (Barreto et al., 2013).

Although less accurate than the multiwavelength Raman lidar, the micro-lidar has the great advantage of being quite automatic and robust. Furthermore, advanced joint sun-photometer/lidar inversion schemes are currently being developed and implemented by LOA, in cooperation with LOSM/BAS (Lopatsin et al., 2012). This new approach called GARRLIC (Generalized Aerosol Retrieval from Radiometer and LIdar Combined data) and proposed in the framework of the ACTRIS project (Aerosol Cloud and TRace gas Infra Structure, www.actris.com) will be very useful in combining multispectral lidar and sun/sky photometer (AOD + Almucantar; Chaikovsky et al., 2010, 2012).

For the current case (single wavelength lidar + sun/sky photometer), the implementation of GARRLIC will not result in major changes as expected from a multiwavelength lidar, but will improve the accuracy of aerosol extinction profile, and the whole archive will be reprocessed. At French national level, ORAURE (Observations en Réseaux des Aérosols à Usage de Recherches Environnementales), a recent initiative supported by CNRS-INSU, will design an observing system merging and managing sun photometers, lidars and in situ data networks.
Acknowledgements. This study was supported by CNRS-INSU, CNES, Lille 1 University and Région Nord-Pas de Calais and FP6/Mobility program under the Marie-Curie project TOTECAT. Authors are very grateful to AERONET (http://aeronet.gsfc.nasa. gov/) team and NOAA HYSPLIT Air Resource Laboratory model (http://ready.arl.noaa.gov/HYSPLIT.php).

The authors want to thank CNRS-DRI for supporting cooperation with Belarus Academy of Science.

Edited by: M. King

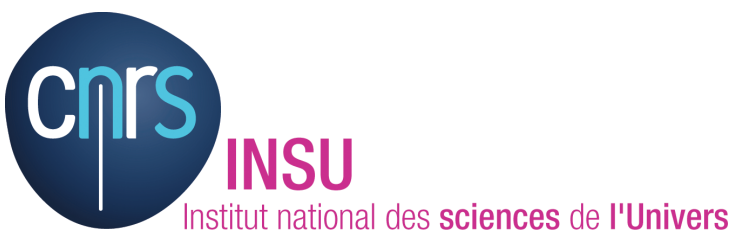

The publication of this article is financed by CNRS-INSU.

\section{References}

Ajtai, N., Stefanie, H., Stoian, L. C., and Oprea, M. G.: The volcanic ash and its impact on European air transport industry: A case study on the detection and impact of the the Eyjafjallajökull volcanic ash plume over North-Western Europe between 14 and 21 April 2010, AES Bioflux, 2, 57-68, 2010.

Ansmann, A., Tesche, M., Groß, S., Freudenthaler, V., Seifert, P., Hiebsch, A., Schmidt, J., Wandinger, U., Mattis, I., Muller, D., and Wiegner, M.: The 16 April 2010 major volcanic ash plume over central Europe: EARLINET LIDAR and AERONET photometer observations at Leipzig and Munich, Germany, Geophys. Res. Lett., 37, L13810, doi:10.1029/2010GL043809, 2010.

Ansmann, A., Tesche, M., Seifert, P., Groß, S., Freudenthaler, V., Apituley, A., Wilson, K. M., Serikov, I., Linné, H., Heinold, B., Hiebsch, A., Schnell, F., Schmidt, J., Mattis, I., Wandinger, U., and Wiegner, M.: Ash and fine-mode particle mass profiles from EARLINET AERONET observations over central Europe after the eruptions of the Eyjafjallajökull volcano in 2010, J. Geophys Res., 116, D00U02, doi:10.1029/2010JD015567, 2011.

Barreto, A., Cuevas, E., Damiri, B., Guirado, C., Berkoff, T., Berjón, A. J., Hernández, Y., Almansa, F., and Gil, M.: A new method for nocturnal aerosol measurements with a lunar photometer prototype, Atmos. Meas. Tech., 6, 585-598, doi:10.5194/amt-6-585-2013, 2013.

Campbell, J. R., Hlavka, D. L., Welton, E. J., Flynn, C. J., Turner, D. D., Spinhirne, J. D., Scott, V. S., and Hwang, I. H.: Fulltime, Eye-Safe Cloud and Aerosol LIDAR Observation at Atmospheric Radiation Measurement Program Sites: Instrument and Data Processing, J. Atmos. Oceanic Technol., 19, 431-442, 2002.

Cattrall, C., Reagan, J., Thome, K., and Dubovik, O.: Variability of aerosol and spectral lidar and backscatter and extinction ratios of key aerosol types derived from selected Aerosol Robotic Network locations, J. Geophys. Res., 110, D10S11, doi:10.1029/2004JD005124, 2005.

Chaikovsky A., Dubovik, O., Goloub, P., Tanre, D., Lopatsin, A., Denisov, S., Lapyonok, T., and Karol., Y.: The retrieval of aerosol 
microphysical properties in the vertical column using combined LIDAR/photometer data: a step to integrating photometer and LIDAR networks, Proceedings of the 25th International Laser Radar Conference, St. Petersburg, 5-9 July 2010, 1087-1091, 2010.

Chaikovsky. A, Dubovik, O., Goloub, P., Tanré, D., Pappalardo, G., Wandinger, U., Chaikovskaya, L., Denisov, S., Grudo, Y., Lopatsin, A., Karol, Y., Lapyonok, T., Korol, M., Osipenko, F., Savitski, D., Slesar, A., Apituley, A., Alados Arboledas, L., Binietoglou, I., Com- eron, A., Kokkalis, P., Granados Muñoz, M., Papayannis, A., Perrone, M. R., Pietruczuk, A., De Tomasi, F., Wagner, J., and Wang, X.: Algorithm and Software for the retrieval of vertical aerosol properties using combined LIDAR/radiometer data: dissemination in EARLINET Network, 26th International Laser Radar Conference, Porto Heli, Peloponnesus, Greece on 25-29 June, 339-402, 2012.

Chazette, P., Bocquet, M., Royer, P., Winiarek, V., Raut, J. C., Labazuy, P., Gouhier, M., Lardier, M., and Cariou, J.P .: Eyjafjallajökull ash concentrations derived from both lidar and modeling, J. Geophys. Res., 117, D00U14, doi:10.1029/2011JD015755, 2012.

Derimian, Y., Dubovik, O., Tanre, D., Goloub, P., Lapyonok, T., and Mortier, A.: Radiative forcing of mixed aerosols: a case study of the Eyjafjallajökull volcano ash layer observed over Lille in 2010, J. Geophys. Res., 117, D00U25, doi:10.1029/2011JD016815, 2012.

Dubovik, O. and King, M. D.: A flexible inversion algorithm for retrieval of aerosol optical properties from Sun and sky radiance measurements, J. Geophys. Res., 105, 20673-20696, 2000.

Dubovik, O., Holben, B. N., Lapyonok, T., Sinyuk, A., Mishchenko, M. I., Yang P., and Slutsker, I.: Non-spherical aerosol retrieval method employing light scattering by spheriods, Geophys. Res. Lett., 29, 541-544, 2002a.

Dubovik, O., Holben, B. N., Eck, T. F., Smirnov, A., Kaufman, Y. J., King, M. D., Tanre, D., and Slutsker, I.: Variability of absorption and optical properties of key aerosol types observed in worldwide locations, J. Atmos. Sci., 59, 590-608, 2002b.

Dubovik, O., Sinyuk, A., Lapyonok, T., Holben, B. N., Mishchenko, M., Yang, P., Eck, T. F., Volten, H., Munoz, O., Veihelmann, B., Van Der Zande, W. J., Leon, J. F., Sorokin, M., and Slutsker, I.: Application of spheroid models to account for aerosol particle nonsphericity in remote sensing of desert dust, J. Geophys. Res., 111, D11208, doi:10.1029/2005JD006619, 2006.

Fernald, F. G.: Analysis of atmospheric LIDAR observations: Some comments, Appl. Opt., 23, 652-653, 1984.

Flentje, H., Heese, B., Reichardt, J., and Thomas, W.: Aerosol profiling using the ceilometer network of the German Meteorological Service, Atmos. Meas. Tech. Discuss., 3, 3643-3673, doi:10.5194/amtd-3-3643-2010, 2010.

Groß S., Gasteiger, J., Freudenthaler, V., Schnell., F., and Wiegner, M.: Characterization of the Eyjafjallajökull ash-plume by means of LIDAR measurements over the Munich EARLINETsite, Proc. SPIE 7832, P. Soc. Photo.-Opt. Ins., SPIE 78320M, doi:10.1117/12.869020, 2010.

Guffanti, M., Mayberry, G. C., Casadevall, T. J., and Wunderman, R.: Volcanic Hazards to airports, Natural Hazards (Special Issue on Aviation Hazards from Volcanoes), Natural Hazards, 51, 287$302,2009$.
Holben, B. N., Eck, T. F., Slutsker, I., Tanre, D., Buis, J. P., Setzer, A., Vermote, E., Reagan, J. A., Kaufman, Y., Nakajima, T., Lavenu, F., Jankowiak, I., and Smirnov, A.: AERONET - A federated instrument network and data archive for aerosol characterization, Remote Sens. Environ., 66, 1-16, 1998.

Holben, B. N., Tanre, D., Smirnov, A., Eck, T. F., Slutsker, I., Abuhassan, N., Newcomb, W. W., Schafer, J., Chatenet, B., Lavenue, F., Kaufman, Y. J., Van De Castle J., Setzer, A., Markham, B., Clark, D., Frouin, R., Halthore, R., Karnieli, A., O'Neill, N. T., Pietras, C., Pinker, R. T., Voss, K., and Zibordi, G.: An emerging ground-based aerosol climatology: Aerosol Optical Depth from AERONET, J. Geophys. Res., 106, 12067-12097, 2001.

Johnson, B., Turnbull, K., Brown, P., Burgess, R., Dorsey, J., Baran, A. J., Webster, H., Hay- wood, J., Cotton, R., Ulanowski, Z., Hesse, E., Woolley, A., and Rosenberg, P.: In situ observations of volcanic ash clouds from the FAAM aircraft during the eruption of Eyjafjallajökull in 2010, J. Geophys. Res., 117, D00U24, doi:10.1029/2011JD016760, 2012a.

Johnson, M. S., Meskhidze, N., and Kiliyanpilakkil1, V. P.: A global comparison of GEOS-Chem-predicted and remotely-sensed mineral dust aerosol optical depth and extinction profiles, J. Adv. Model. Earth Syst., 4, M07001, doi:10.1029/2011MS000109, 2012b.

Kaaden, N., Massling, A., Schladitz, A., Müller, T., Kandler, K., Schütz, L., Weinzierl, B., Petzold, A., Tesche, M., Leinert, S., Deutscher, C., Ebert, M., Weinbruch, S., and Wiedensohler, A.: State of mixing, shape factor, number size distribution, and hygroscopic growth of the Saharan anthropogenic and mineral dust aerosol at Tinfou, Morocco, Tellus, 61B, 51-63, doi:10.1111/j.1600-0889.2008.00388.x, 2008.

Klett, J. D.: Stable analytical inversion solution for processing LIDAR returns, Appl. Opt., 20, 211-220, 1981.

Léon, J.-F., Derimian, Y., Chiapello, I., Tanré, D., Podvin, T., Chatenet, B., Diallo, A., and Deroo, C.: Aerosol vertical distribution and optical properties over M'Bour $\left(16.96^{\circ} \mathrm{W} ; 14.39^{\circ} \mathrm{N}\right)$, Senegal from 2006 to 2008, Atmos. Chem. Phys., 9, 9249-9261, doi:10.5194/acp-9-9249-2009, 2009.

Lopatsin, A., Dubovik, O., Chaikovsky, A., and Goloub, P.: An algorithm for enhanced characterization of atmospheric aerosols using combination of active and passive remote observations, NATO advanced study Institute "Special Detection Technique (Polarimetry) and Remote Sensing", Kiev, 12-25, 2010.

Lopatsin, A., Dubovik, O., Chaikovsky, A., and Goloub, P.: Exploring the synergy of active and passive remote observations for enhancement of atmospheric aerosol remote sensing, IRS2012-457, Berlin, Germany, 2012.

Mattis, I., Siefert, P., Müller, D., Tesche, M., Hiebsch, A., Kanitz, T., Schmidt, J., Fin- ger, F., Wandinger, U., and Ansmann, A.: Volcanic aerosol layers observed with multi-wavelength Raman LIDAR over central Europe in 2008-2009, J. Geophys. Res., 115, D00L04, doi:10.1029/2009JD013472, 2010.

Marshak, A., Knyzaikhin, Y., Evans, K. D., and Wiscombe, W. J.: The "RED versus NIR" Plane to Retrieve Broken-Cloud Optical Depth from Ground-Based Measurements, J. Atmos. Sci., 61, 1911-1925, 2004.

Mona, L., Amodeo, A., D’Amico, G., Giunta, A., Madonna, F., and Pappalardo, G.: Multi-wavelength Raman lidar observations of the Eyjafjallajökull volcanic cloud over Potenza, southern Italy, Atmos. Chem. Phys., 12, 2229-2244, doi:10.5194/acp-12-2229- 
2012, 2012.

Mortier, A., Goloub, P., Holben, B., Podvin, T., Blarel, L., Verwaerde, C., Karol, Y., Slutsker, I., Balois, J.-Y., Tanre, D., Berkoff, T., Victori, S., and Mathieu, R.: Aerosol Spatial Distribution during DRAGON experiment as seen by a mobile groundbased LIDAR-sunphotometer system-Preliminary results, Reviewed and revised papers of the 26th International Lidar Radar Conference, Porto Heli, Peloponnesus, Greece on 25-29 June, 411-414, 2012.

Pelon, J., Mallet, M., Mariscal, A., Goloub, P., Tanré, D., Bou Karam, D., Flamant, C., Haywood, J., Pospichal, B., and Victori, S.: Characterization of Biomass burning aerosol from microLIDAR observation at Djoudou (Benin) during AMM-SOP0/DABEX, J. Geophys. Res., 113, D00C18, doi:10.1029/2008JD009976, 2008.

Pueschel, R. F., Livingston, J. M., Ferry, G. V., and DeFelice, T. E.: Aerosol abundances and optical characteristics in the pacific basin free troposphere, Atmos. Environ., 28, 951-960, 1994.

Randriamiarisoa, H., Chazette, P., Couvert, P., Sanak, J., and Mégie, G.: Relative humidity impact on aerosol parameters in a Paris suburban area, Atmos. Chem. Phys., 6, 1389-1407, doi:10.5194/acp-6-1389-2006, 2006.

Royer, P., Chazette, P., Sartelet, K., Zhang, Q. J., Beekmann, M., and Raut, J.-C.: Comparison of lidar-derived $\mathrm{PM}_{10}$ with regional modeling and ground-based observations in the frame of MEGAPOLI experiment, Atmos. Chem. Phys., 11, 1070510726, doi:10.5194/acp-11-10705-2011, 2011.

Russell, P. B., Swissier, J. T., and McCormick, P. M.: Methodology for error analysis and simulation of LIDAR aerosol measurements, Appl. Opt., 18, 3783-3797, 1979.

Schumann, U., Weinzierl, B., Reitebuch, O., Schlager, H., Minikin, A., Forster, C., Baumann, R., Sailer, T., Graf, K., Mannstein, H., Voigt, C., Rahm, S., Simmet, R., Scheibe, M., Lichtenstern, M., Stock, P., Rüba, H., Schäuble, D., Tafferner, A., Rautenhaus, M., Gerz, T., Ziereis, H., Krautstrunk, M., Mallaun, C., Gayet, J.F., Lieke, K., Kandler, K., Ebert, M., Weinbruch, S., Stohl, A., Gasteiger, J., Groß, S., Freudenthaler, V., Wiegner, M., Ansmann, A., Tesche, M., Olafsson, H., and Sturm, K.: Airborne observations of the Eyjafjalla volcano ash cloud over Europe during air space closure in April and May 2010, Atmos. Chem. Phys., 11, 2245-2279, doi:10.5194/acp-11-2245-2011, 2011.
Schuster, G. L., Vaughan, M., MacDonnell, D., Su, W., Winker, D., Dubovik, O., Lapyonok, T., and Trepte, C.: Comparison of CALIPSO aerosol optical depth retrievals to AERONET measurements, and a climatology for the lidar ratio of dust, Atmos. Chem. Phys., 12, 7431-7452, doi:10.5194/acp-12-7431-2012, 2012.

Sigmundsson, F., Hreinsdóttir, S., Hooper, A., Árnadóttir, T., Pedersen, R., Roberts, M. J., O'skarsson, N., Auriac, A., Decriem, J., Einarsson, P., Geirsson, H.,Hensch, M., Ófeigsson, B. G., Sturkell, E., Sveinbjörnsson, H., and Feigl, K. L.: Intrusion triggering of the 2010 Eyjafjallajökull explosive eruption, Nature, 468, 426-430, doi:10.1038/nature09558, 2010.

Sloane, C. S.: Optical properties of aerosols of mixed composition, Atmos. Environ., 18, 871-878, 1984.

Weber, K., Eliasson, J., Vogel, A., Fischer, C., Pohl, T., van Haren, G., Meier, M., Grobety, B., and Dahmann, D.: Airborne insitu investigations of the Eyjafjallajökull volcanic ash plume on Iceland and over north-western Germany with light aircrafts and optical particle counters, Atmos. Environ., 48, 9-21, doi:10.1016/j.atmosenv.2011.10.030, 2011.

Weitkamp, C.: Lidar - Range-Resolved Optical Remote Sensing of the Atmosphere, Springer, 133 pp., 2005.

Welton, E. J., Voss, K. J., Gordon, H. R., Maring, H., Smirnov, A., Holben, B. N., Schmid, B., Livingston, J. M., Russell, P. B., Durkee, P. A., Formenti, P., and Andreae, M. O.: Ground-based LIDAR measurements of aerosols during ACE-2: instrument description, results, and comparisons with other ground-based and airborne measurements, Tellus, 52, 635-650, 2000.

Wiegner, M., Gasteiger, J., Groß, S., Schnell, F., Freudenthaler, V., and Forkel, R.: Characterization of the Eyjafjallajökull ashplume: Potential of LIDAR remote sensing, Phys. Chem. Earth, 45-46, 79-86, doi:10.1016/j.pce.2011.01.006, 2011. 